\title{
PERANCANGAN APLIKASI PENGENALAN BUDAYA INDRAMAYU BERBASIS ANDROID
}

\author{
Nico Andriantor ${ }^{1}$, Rizki Ridwan ${ }^{2}$, Aulia Ar Rakhman Awaludin ${ }^{3}$ \\ Program Studi Teknik Informatika, Fakultas Teknik dan Ilmu Komputer, \\ Universitas Indraprasta PGRI \\ Jalan Raya Tengah No 80, Kelurahan Gedong, Pasar Rebo, Jakarta Timur \\ nicoan45@gmail.com ${ }^{1}$, rizki8992@gmail.com ${ }^{2}$, aulia_awaludin@yahoo.co.id ${ }^{3}$
}

\begin{abstract}
Abstrak
Perkembangan ilmu pengetahuan dan teknologi saat ini berkembang sangat pesat. Kemajuan akan ilmu pengetahuan dan teknologi telah berperan penting di dalam masyarakat. Oleh karena itu, dengan pemanfaatan teknologi khususnya smartphone dibuatlah sebuah aplikasi yang akan menampilkan informasi mengenai kebudayaan untuk membantu mengenalkan dan memberikan pengetahuan mengenai kebudayaan Indonesia khususnya budaya Indramayu. Dengan aplikasi pengenalan budaya Indramayu ini diharapkan dapat membantu masyarakat luas untuk mempelajari Bahasa dan budaya Indramayu di mana saja tanpa harus membawa buku. Penelitian ini menggunakan metode kualitatif, yaitu suatu penelitian kontekstual yang menjadikan manusia sebagai instrumen, dan disesuaikan dengan situasi yang wajar dalam kaitannya dengan pengumpulan data yang pada umumnya bersifat kualitatif. Penelitian ini bertujuan untuk menjadikan aplikasi pengenalan budaya Indramayu sebagai solusi atas kurangnya pengetahuan masyarakat tentang budaya Indramayu agar masyarakat lebih mudah mempelajari budaya Indramayu dan generasi muda lebih minat untuk mempelajari dan melestarikan budaya Indramayu.
\end{abstract}

Kata Kunci: Perancangan Aplikasi, Aplikasi Android, Aplikasi Pengenalan Budaya, Budaya Indramayu

\begin{abstract}
The development of science and technology is currently developing very rapidly. Advances in science and technology have played an important role in society. Therefore, with the use of technology, especially smartphones, an application is made that will display information about culture to help introduce and provide knowledge about Indonesian culture, especially Indramayu culture. With the application of Indramayu culture introduction, it is hoped that it can help the wider community to learn Indramayu language and culture anywhere without having to carry books. This study uses a qualitative method, which is a contextual study that uses humans as instruments, and is adapted to a reasonable situation in activating it with qualitative data. This study aims to make the application of Indramayu culture introduction as a solution based on people's knowledge of Indramayu culture so that people can more easily learn Indramayu culture and create more interest in learning and preserving Indramayu culture.
\end{abstract}

Keywords: Application Design, Android Application, Cultural Introduction Application, Indramayu Culture

\section{PENDAHULUAN}

Perkembangan ilmu pengetahuan dan teknologi saat ini berkembang sangat pesat. Teknologi telah ikut ambil di semua aspek kehidupan manusia. Salah satunya adalah teknologi mobile yang terkenal di masyarakat, telah banyak mempengaruhi kehidupan. Bahasa Indramayu merupakan salah satu ragam Bahasa yang ada di Indonesia, Bahasa jawa dialek Indramayu yang menjadi ciri khas Bahasa warga Indramayu yang berasal dari Jawa Barat. Banyak orang yang beranggapan bahwa Provinsi Jawa Barat sudah pasti menggunakan Bahasa Sunda terutama orang yang berasal dari luar Jawa Barat atau bahkan orang Jawa Barat pun beranggapan bahwa Jawa Barat itu Sunda. kalau Bahasa Jawa itu Provinsi Jawa Tengah, Daerah Istimewa Yogyakarta dan Jawa Timur. Anggapan seperti itu tidak bisa di samakan semua, karena batas wilayah Administratif Pemerintah belum tentu sama dengan batas kebudayaan dan juga Bahasa. Dalam kesempatan ini peneliti tertarik membuat aplikasi dengan judul "Perancangan Aplikasi Pengenalan Budaya Indramayu Berbasis Android". Peneliti berharap semoga aplikasi ini dapat memudahkan pengguna dalam mendapatkan informasi dan pengetahuan mengenai budaya Indramayu dengan data yang lebih cepat, tepat dan efisien. Bahasa adalah karakter yang unik dan manusiawi untuk membedakan antara manusia dengan makhluk lainnya. Bahasa sebagai sistem komunikasi merupakan bagian dari sistem budaya, terlebih lagi bahasa merupakan ciri utama budaya. Bahasa juga berbaur dengan 
semua aspek budaya. Kebudayaan manusia mustahil tanpa bahasa karena bahasa merupakan faktor utama yang akan menentukan terbentuknya kebudayaan (Rina Devianty, 2017). Perancangan adalah sebuah proses untuk mendefinisikan sesuatu yang akan melibatkan deskripsi mengenai arsitektur serta detail komponen dikerjakan dengan menggunakan teknik yang bervariasi serta didalamnnya dan juga keterbatasan yang akan dialami dalam proses pengerjaannya (Rizky, 2011). Aplikasi adalah satu unit perangkat lunak yang dibuat untuk melayani kebutuhan akan beberapa aktivitas seperti sistem perniagaan, game, pelayanan masyarakat, periklanan, atau semua proses yang hampir dilakukan oleh manusia (Pramana, 2012). Sistem informasi terdiri dari komponenkomponen yang disebut dengan istilah blok bangunan, yang terdiri dari blok masukan, blok model, blok keluaran, blok teknologi, blok basis data, dan blok kendali, sebagai suatu sistem. Keenam blok tersebut saling berinteraksi satu dengan yang lain membentuk satu kesatuan untuk mencapai sasaran (Sutabri, 2012). Android merupakan sistem operasi untuk perangkat telepon selular berbasis Linux. Android menyediakan platform terbuka bagi para pengembang untuk menciptakan aplikasi mereka sendiri untuk digunakan oleh bermacam piranti bergerak. Android umum digunakan di smartphone dan juga tablet PC. Fungsi Android sama seperti sistem operasi Symbian di Nokia, IOS di Apple dan Blackberry OS (Safaat, 2011).

\section{PENELITIAN RELEVAN}

Penelitian yang digunakan sebagai acuan dalam penelitian ini adalah sebagai berikut: penelitian yang dilakukan oleh Murtiwiyati dan Lauren (2013) dengan judul Rancang Bangun Aplikasi Pembelajaran Budaya Indonesia Untuk Anak Sekolah Dasar Berbasis Android. Hasil penelitian tersebut adalah aplikasi yang bertujuan untuk memberikan informasi tentang budaya Indonesia dan aplikasi tersebut juga dilengkapi dengan latihan-latihan soal seputar kebudayaan yang sudah di jelaskan di aplikasi tersebut. Pembuatan aplikasi pembelajaran budaya ini dengan menggunakan software berbasis Java dan XML. Pengembangan aplikasi ini menggunakan model waterfall (Murtiwiyati \& Lauren, 2013).

Penelitian oleh Adam Saputra (2014) dengan judul Perancangan Edukasi Pengenalan Nama Hewan Dalam Bahasa Inggris. Hasil dari penelitian tersebut adalah aplikasi untuk membantu proses belajar mengajar sehingga memudahkan guru mata pelajaran tersebut dalam menyampaikan materi yang di ajarkan agar siswa tidak merasa bosan dalam memahami materi dari pelajaran tersebut. Untuk membuat media pembelajaran yang menarik dengan merancang sebuah aplikasi Android dan metode yang digunakan dalam perancangan aplikasi ini adalah waterfall sama dengan metode yang di gunakan pada Perancangan Aplikasi Pengenalan Budaya Indramayu Berbasis Android. Dimana model ini telah terorganisasi secara teratur sehingga resiko akan terjadinya pengulangan proses langkah kerja akan terhindar sebab dilakukan secara berurutan (Saputra et al., 2014).

Penelitian oleh Kusniyati dan Pangondian Sitanggang (2016) dengan judul Aplikasi edukasi Budaya Toba Samosir Berbasis Android. Hasil dari penelitian tersebut adalah aplikasi untuk mempermudah penggunanya mengakses bebagai informasi kebudayaan Toba Samosir melalui aplikasi edukasi budaya Toba Samosir berbasis Android ini. Banyak dari lapisan masyarakat sekarang ini telah menggunakan teknologi informasi dan komunikasi sebagai salah satu sektor kompetitif yang bisa menambah nilai dari proses bisnis yang dijalankan (Kusniyati \& Pangondian Sitanggang, 2016).

\section{METODE PENELITIAN}

Penelitian ini menggunakan metode kualitatif, metode penelitian pada dasarnya merupakan cara ilmiah untuk mendapatkan data tujuan Dan kegunaan tertentu. Baik berupa data primer maupun data sekunder yang dapat digunakan untuk menyusun karya ilmiah dan kemudian menganalisis faktor-faktor yang berhubungan dengan pokok-pokok permasalahan sehingga akan didapat suatu kebenaran atas data yang diperoleh (Sugiyono, 2008).

Metode pengembangan sistem menggunakan Waterfall, merupakan metode pengembangan perangkat lunak yang selalu diperkenalkan kepada mahasiswa jurusan ilmu komputer/teknik informatika melalui suatu matakuliah. Hal ini mengakibatkan metode Waterfall hampir selalu digunakan sebagai metode untuk pengembangan perangkat lunak (Binanto, 2014).

Metode penelitian kuantitatif dapat diartikan sebagai metode penelitian yang berlandaskan pada filsafat positivisme, digunakan untuk meneliti pada populasi atau sampel tertentu. Teknik 
pengambilan sampel pada umumnya dilakukan secara random, pengumpulan data menggunakan instrumen penelitian, analisis data bersifat kuantitatif/statistik dengan tujuan untuk menguji hipotesis yang telah ditetapkan (Sugiyono, 2010).

\section{HASIL DAN PEMBAHASAN}

Flowchart atau diagram alir adalah sebuah jenis diagram yang mewakili algoritma, alir kerja atau proses yang menampilkan langkah-langkah dalam bentuk simbol-simbol grafis dan urutannya dihubungkan dengan panah. Diagram ini mewakili ilustrasi atau penggambaran penyelesaian masalah. Diagram alir digunakan untuk menganalisis, mendesain, mendokumentasi, dan memanajemen sebuah proses atau program di belakang bidang. Flowchart pada aplikasi pengenalan budaya Indramayu sebagai berikut:

\section{Flowchart Splash Screen}

Merupakan awal pertama kali muncul saat membuka aplikasi sebelum masuk ke menu utama.

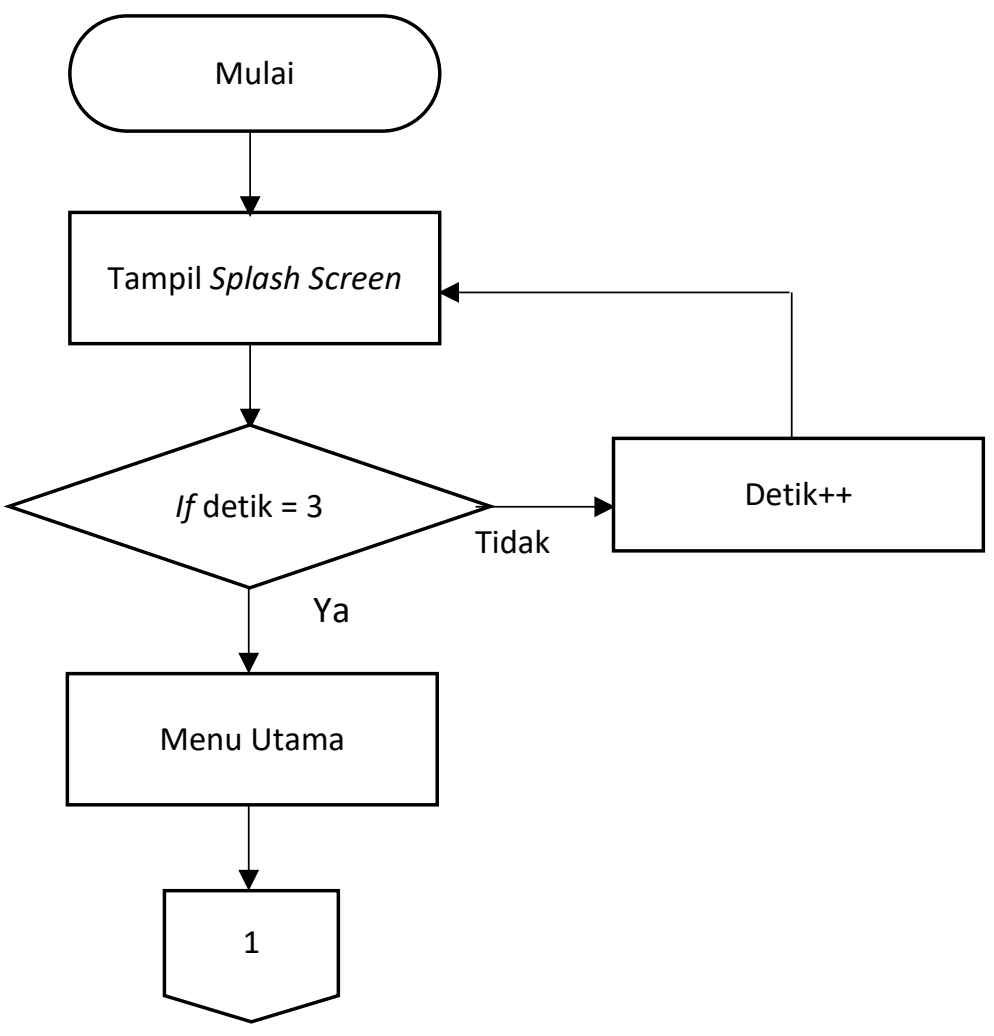

Gambar 1. Flowchart Splash Screen

\section{Flowchart Menu Utama}

Pada saat memasuki halaman menu utama maka terdapat 7 pilihan menu yaitu, sejarah, budaya, Bahasa, wisata, makanan khas, kuis dan about. Jika memilih list pilihan yang ada pada menu budaya maka akan menampilkan informasi detail dari budaya yang di pilih, jika memilih list pilihan yang ada pada menu Bahasa maka akan menampilkan informasi detail dari Bahasa yang di pilih, jika memilih list pilihan yang ada pada menu wisata maka akan menampilkan informasi detail dari wisata yang di pilih, , jika memilih list pilihan yang ada pada menu makanan khas maka akan menampilkan informasi detail dari makanan khas Indramayu yang di pilih, memilih menu kuis maka akan tampil halaman kuis yang berisikan pertanyaan-pertanyaan mengenai materi yang ada pada aplikasi pengenalan budaya Indramayu, jika memilih list pilihan yang ada pada menu about maka akan menampilkan informasi detail dari peneliti melalui sosial media yang di pilih. 


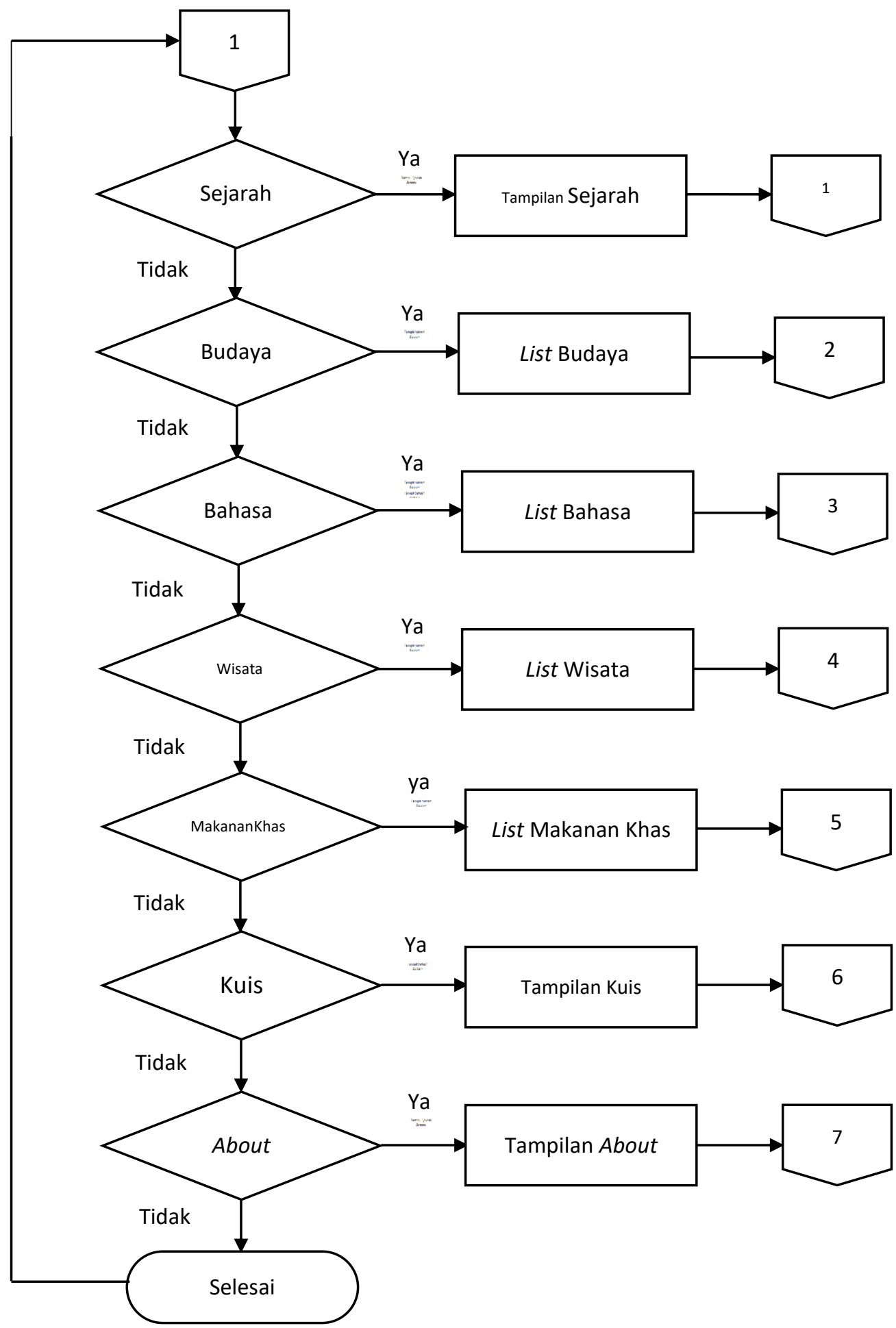

Gambar 2. Flowchart Menu Utama 


\section{Tampilan Aplikasi}

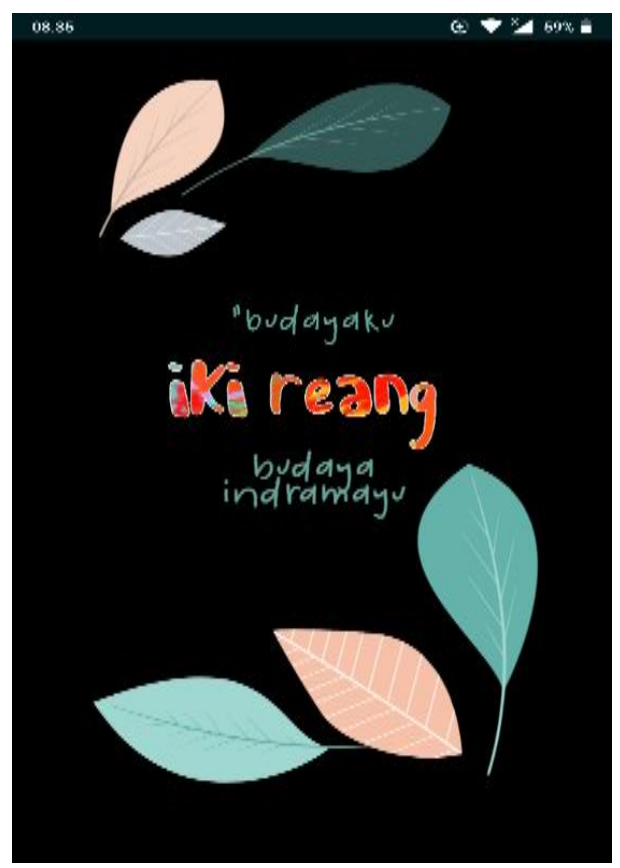

Gambar 3. Tampilan Layar Splash Screen

Merupakan tampilan awal yang pertama kali muncul saat membuka aplikasi sebelum ke menu utama.

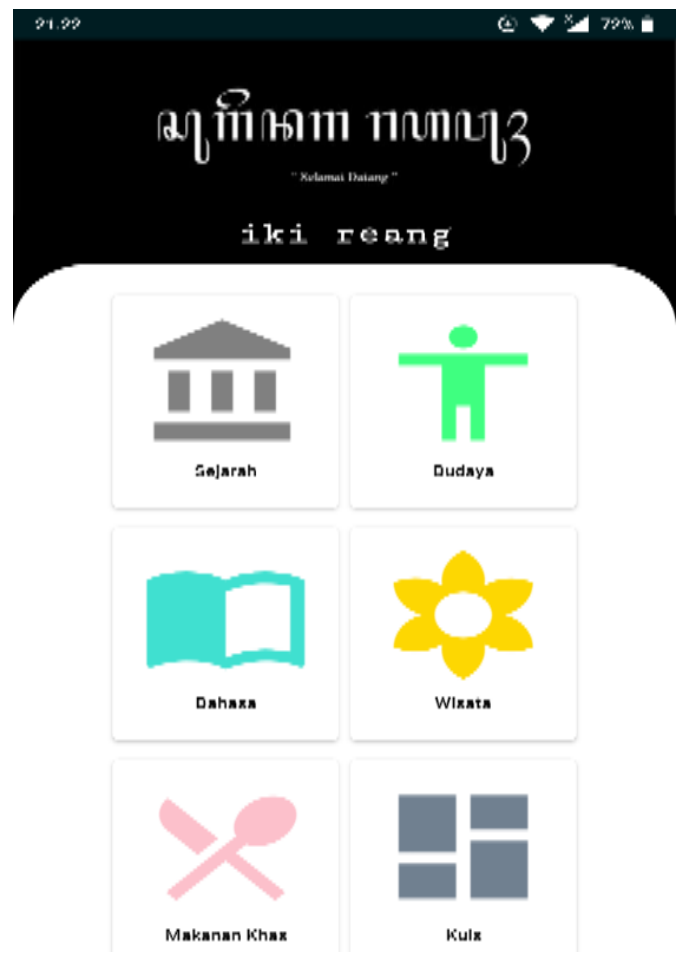

Gambar 4. Tampilan Layar Menu Utama

Merupakan menu yang muncul setelah splash screen, terdapat 7 (tujuh) button pilihan yang berfungsi untuk masuk ke halaman selanjutnya. 


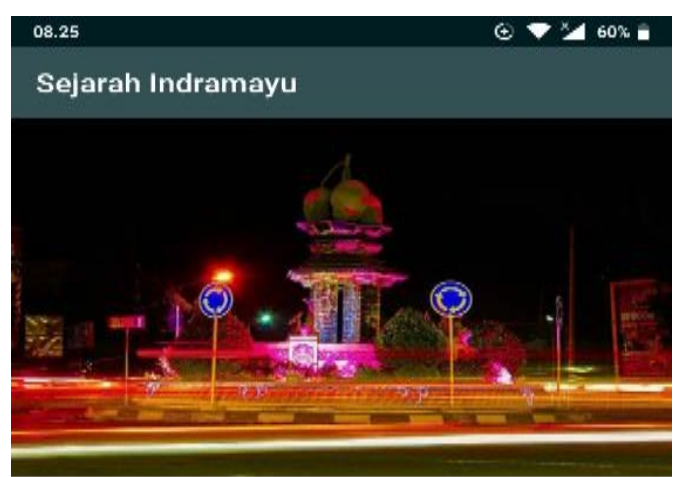

Sejarah Indramayu

Memurut Tim Panitia Pencliti Scjaralı Kabupaten Indramayu balıwa hari jadi Indramayu jatul pada tanghal 7 Oktober 1527 M yang telih disathka pada sidang Pleno DPRD Kabupaten Daerah tingkat II Indramayu pada tanggal 24 Juni 1977 dan ditelapkan dalam Peraturan Daerah Kabupaten Daerah tingkat II Indramayu.

Nomor 122 Tahum 1977 tentang Penetapan Hari dadi Indramayn, dimana dalam Peraturan Dacral tersehut disebutkan bahwa hari jadi Indramayu ditetapkan jatuh pada tanggal 7 (tujuh) Oktober $1527 \mathrm{M}$ hart Jumat Kliwon tanggal 1 Mulsaram 9,34 $\mathrm{H}$.

\section{Gambar 5. Tampilan Layar Sejarah}

Merupakan menu yang menampilkan informasi mengenai sejarah Indramayu.

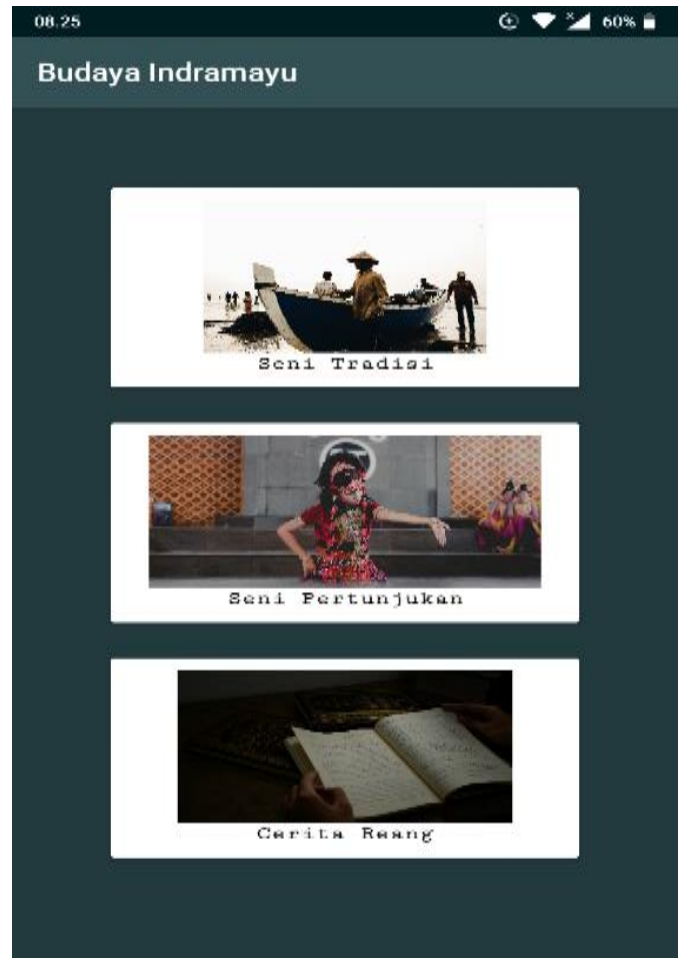

Gambar 6. Tampilan Layar Budaya

Merupakan menu yang menampilkan budaya Indramayu berfungi untuk masuk ke halaman selanjutnya. 


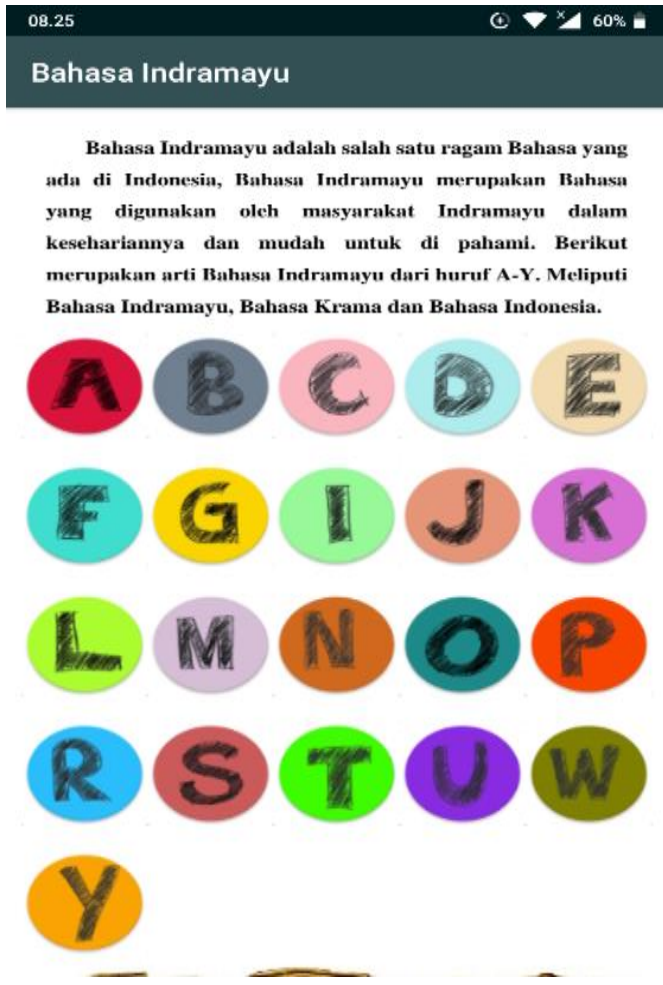

Gambar 7. Tampilan Layar Bahasa

Merupakan menu yang menampilkan Bahasa Indramayu berfungi untuk masuk ke halaman selanjutnya.

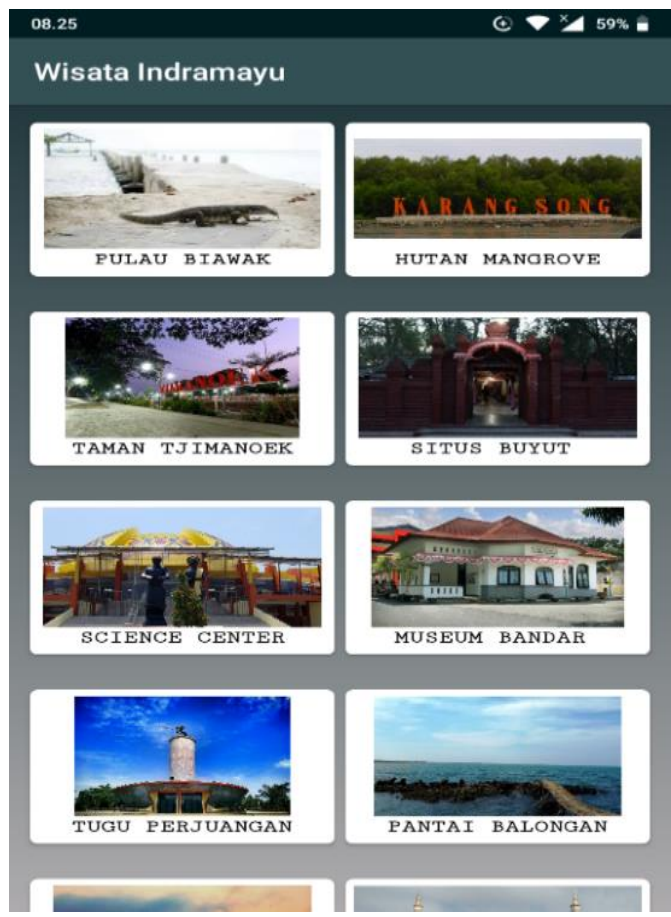

Gambar 8. Tampilan Layar Wisata

Merupakan menu yang menampilkan wisata Indramayu berfungi untuk masuk ke halaman selanjutnya. 


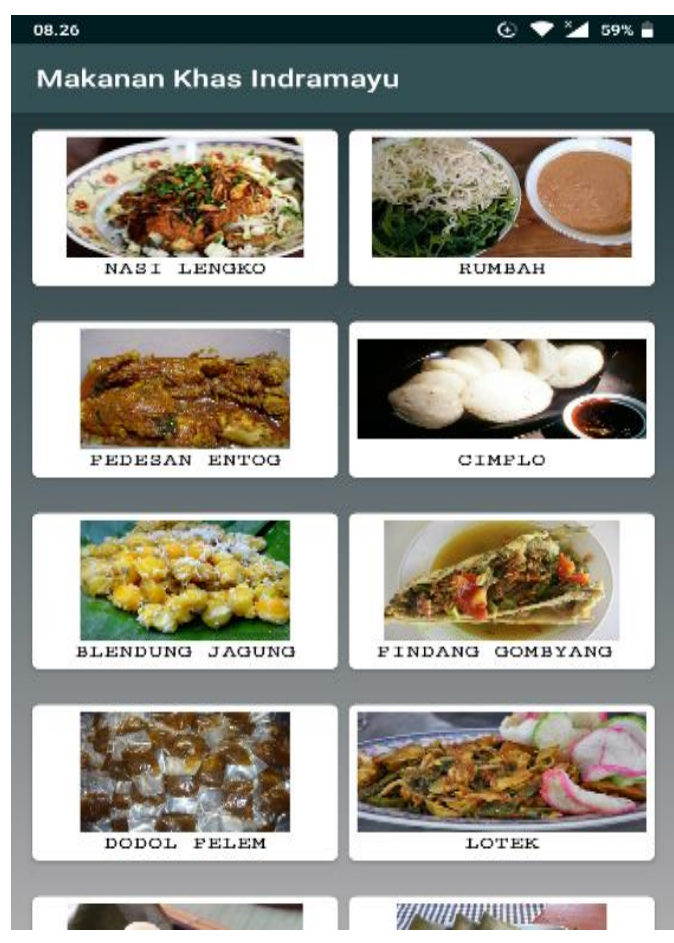

Gambar 9. Tampilan Layar Makanan Khas

Merupakan menu yang menampilkan makanan khas Indramayu berfungi untuk masuk ke halaman selanjutnya.

\section{SIMPULAN}

Simpulan dari penelitian yang berjudul "Perancangan Aplikasi Penggenalan Budaya Indramayu Berbasis Android" adalah sebagai berikut:

1. Diharapkan dengan adanya aplikasi pengenalan budaya Indramayu dapat memudahkan pengguna dalam mendapatkan informasi mengenai budaya dan Bahasa Indramayu.

2. Di zaman yang sangat berkembang pesat seperti sekarang ini, khususnya dalam bidang teknologi, aplikasi-aplikasi yang ada pada smartphone yang dibuat agar memicu minat pengguna dalam mengetahui informasi melalui aplikasi Android. Aplikasi yang dirancang diharapkan dapat menumbuhkan lebih banyak minat untuk mempelajari budaya Indramayu dan mengenalkannya.

\section{DAFTAR PUSTAKA}

Binanto, I. (2014). Analisa Metode Classic Life Cycle ( Waterfall ) Untuk Pengembangan Perangkat Lunak Multimedia. Jurnal Universitas Sanata Dharma Yogyakarta. https://doi.org/10.13140/2.1.1586.4968

Kusniyati, H., \& Pangondian Sitanggang, N. S. (2016). APLIKASI EDUKASI BUDAYA TOBA SAMOSIR BERBASIS ANDROID. JURNAL TEKNIK INFORMATIKA. https://doi.org/10.15408/jti.v9i1.5573

Murtiwiyati, \& Lauren, G. (2013). Rancang Bangun Aplikasi Pembelajaran Budaya Indonesia Untuk Anak Sekolah Dasar berbasis Android. Jurnal Ilmiah.

Pramana, H. W. (2012). Aplikasi Inventory Berbasis Access 2003. Jakarta: PT. Elex Media Komputindo.

Prof. Dr. Sugiyono. (2008). Metode Penelitian Pendidikan (Pendekatan Kuantitatif, Penelitian Kualitatif, dan R\&D). In Metode Penelitian Pendidikan Pendekatan Kuantitatif, Kualitatif Dan R\&D.

Rizky, Soetam. (2011). Konsep Dasar Rekayasa Perangkat Lunak. Jakarta: Prestasi Pustaka.

Rina Devianty. (2017). BAHASA SEBAGAI CERMIN KEBUDAYAAN. JURNAL TARBIYAH.

Safaat, N. (2011). Pemrograman Aplikasi Mobile Smartphone dan Tablet PC Berbasis Android. Bandung: Informatika Bandung. In Android.

Saputra, A., Beny, \& Nugroho, A. (2014). Perancangan Edukasi Pengenalan Nama Hewan Dalam Bahasa Inggris (Studi Kasus : Sdn.58/Vii Teluk Rendah Sarolangun). Jurnal Ilmiah Media Processor, 9(1), 54-66.

Sugiyono. (2010). Metode Penelitian Bisnis. Pendekatan Kuantitatif, kualitatif dan R \& D. Bandung: Alfabeta.

Sutabri, T. (2012). Konsep Sistem Informasi. In Jurnal Administrasi Pendidikan UPI. 